ISSN 1678-3921

Journal homepage: www.embrapa.br/pab

For manuscript submission and journal contents, access: www.scielo.br/pab

\section{Spatial and temporal evolution of imidazolinone-resitant red rice in 'Clearfield' rice cultivations}

\begin{abstract}
The objective of this work was to evaluate the distribution of imidazolinone-resistant(IMI-R) red rice (Oryza sativa) populations, the frequency of alleles conferring resistance to IMI, and the adoption of agronomic practices applied to red rice control, across growing seasons and production regions of the state of Rio Grande do Sul (RS), Brazil. In the experiment, 1,008 red rice populations were screened for resistance to IMI, 760 IMI-R red rice plants were genotyped for the acetolactate synthase (ALS) alleles conferring resistance to IMI, and 40 'Clearfield' rice growers were surveyed. IMI-R red rice populations were widespread throughout RS since the 2006/2007 growing season, with a higher initial frequency in the Depressão Central and Fronteira Sul production regions. The occurrence of IMI-R red rice ranged from 1.6 to 3.5 years after 'Clearfield' rice release. Gly654Glu was the most frequent ALS mutation in IMI-R red rice populations, which shows a gene flow from the most used 'Clearfield' rice cultivars to the red rice plants. Crop rotation systems and certified seed were used by only $30 \%$ of the surveyed growers of 'Clearfield' rice, with lower percentages in the production regions where IMI-R red rice appeared faster.
\end{abstract}

Index terms: Oryza sativa, gene flow, herbicide resistance, weedy rice.

\section{Evolução espacial e temporal do arroz- vermelho resistente às imidazolinonas em cultivos de arroz 'Clearfield'}

Resumo - O objetivo deste trabalho foi avaliar a distribuição de populações de
arroz-vermelho (Oryza sativa) resistente às imidazolinonas (R-IMI), a frequência
dos alelos que conferem resistência às IMI, e a adoção de práticas agronômicas
aplicadas ao controle do arroz-vermelho, em estações de cultivo e regiões
produtoras de arroz do Estado do Rio Grande do Sul (RS), Brasil. No experimento,
1.008 populações de arroz-vermelho foram avaliadas quanto à resistência às IMI,
760 plantas de arroz-vermelho R-IMI foram genotipadas quanto aos alelos da
acetolactato sintase (ALS) que conferem resistência às IMI, e 40 produtores de
arroz 'Clearfield' foram entrevistados. As populações de arroz-vermelho R-IMI
estavam amplamente distribuídas no RS, desde a época de cultivo em 2006/2007,
com maior frequência inicial nas regiões orizícolas da Depressão Central e da
Fronteira Oeste. A ocorrência de arroz-vermelho R-IMI variou de 1,6 a 3,5 anos
após o lançamento do arroz 'Clearfield'. A mutação Gly654Glu da ALS foi mais
frequente nas populações de arroz-vermelho R-IMI, o que indica a ocorrência de
fluxo gênico da cultivar de arroz 'Clearfield' para as plantas de arroz-vermelho. A
rotação de culturas e o uso de sementes certificadas foram adotados por apenas
$30 \%$ dos produtores de arroz 'Clearfield' entrevistados, com menores percentagens
nas regiões em que o arroz-vermelho R-IMI apareceu mais rápido.

Termos para indexação: Oryza sativa, fluxo gênico, resistência a herbicidas, arroz-vermelho. 


\section{Introduction}

Red rice is one of the most damaging weeds of rice cultivations in several regions of the world (DurandMorat et al., 2018). Rice and red rice are genetically similar and belong to the same species, Oryza sativa L., and thus red rice cannot be selectively controlled with herbicides in rice cultivations (Burgos et al., 2008; Kanapeckas et al., 2018). Clearfield (CL) technology, which provides selective red rice control through imidazolinone resistance, was developed through induced mutagenesis in rice (Singh et al., 2017; Roso et al., 2010), and has been transferred to commercial cultivars using conventional breeding. CL rice was introduced in the early 2000s in the USA (Gealy et al., 2003), several Latin American countries (Merotto et al., 2016), and Europe (Busconi et al., 2012), where it has been widely adopted. The key factor for this broad adoption was the possibility to selectively control red rice in flooded rice fields (Delouche et al., 2007; Nadir et al., 2017; Gao et al., 2018).

Red rice control, combined with better fertilizer practices and sowing time, have increased the average grain yield of CL rice by $2 \mathrm{Mg} \mathrm{ha}^{-1}$ in Southern Brazil (Roso et al., 2010). However, these benefits have encouraged the use of this technology continuously and, as a consequence, imidazolinone-resistant (IMI-R) red rice was identified in commercial rice fields just a few seasons after CL rice was released in the USA (Zhang et al., 2006; Ellstrand, 2018), Brazil (Menezes et al., 2009), Italy (Busconi et al., 2012), and other regions of Europe and Latin America (Ziska et al., 2015). In addition to the herbicide selection pressure, the gene flow from CL rice to red rice escapees has contributed to the IMI-R red rice evolution (Goulart et al., 2012; Bzour et al., 2018).

Approximately $65 \%$ of the milled rice production in Brazil is originated from the flooded rice cropping systems of Rio Grande do Sul state (RS), according to Conab (2018). The flooded rice fields in the RS state are divided into six production regions based on agro-environmental factors such as climate, soil characteristics, and crop management. There are well-defined differences among these regions for air temperature, soil drainage, and fertility (Cruz, 2010), and other environmental characteristics that influence the feasibility of the adoption of agronomic practices, as well as weed management strategies applied to red rice control (Menezes et al., 2013). It was hypothesized that there may be differences between rice production regions, for the evolution of IMI-R red rice in rice fields of the RS state, and that these differences impair the evolution of herbicide resistance. The knowledge of the factors related to the evolution of herbicide resistance in red rice is important to prevent its occurrence in new CL rice areas, and for new herbicide-resistant technologies.

The objective of this work was to evaluate the distribution of IMI-R red rice populations, the frequency of alleles conferring resistance to IMI, and the adoption of agronomic practices applied to red rice control, across growing seasons and production regions in Rio Grande do Sul state, Brazil.

\section{Materials and Methods}

One thousand eight rice fields were sampled from the 2006/2007 to 2011/2012 growing seasons in 40 counties, in six rice production regions, in the state of Rio Grande do Sul (RS), Brazil. The number of rice fields evaluated was $228,267,310,140,44$, and 19 , for the growing seasons of 2006/2007, 2007/2008, 2008/2009, 2009/2010, 2010/2011, and 2011/2012, respectively. The sampling fields had a history of use of 'Clearfield' rice cultivars, and of red rice escapees observed after the application of IMI herbicides. Red rice seed were randomly collected from 20 mature plants (at least 1,000 viable seed per sample), which were combined into a single composite sample.

Red rice plants were grown under greenhouse conditions from 2006/2007 to 2011/2012 growing seasons, at the field station of Instituto Rio Grandense do Arroz (IRGA), in the municipality of Cachoeirinha, RS, Brazil. Initially, seed were exposed to a dormancybreaking treatment of $40^{\circ} \mathrm{C}$ for two days. After that, seed were sown in plastic trays $(85 \mathrm{~cm}$ wide by $45 \mathrm{~cm}$ long) with a capacity of $10 \mathrm{~L}$, and filled with hydromorphic soil. Each tray contained six red rice populations sown in rows spaced at $10 \mathrm{~cm}$ apart and

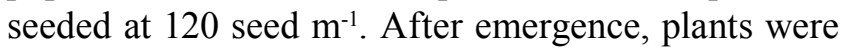
thinned to 50 plants per population. In addition, each tray contained the commercial IMI-susceptible 'IRGA 417', and IMI-R 'Puitá INTA CL' cultivars, as positive and negative lateral-check controls, respectively. The irrigation was performed daily, and the trays were rearranged weekly in the greenhouse to avoid light effects. 
The experiment was arranged in a completely randomized design with four replicates. A discriminatory herbicide dose was defined in a preliminary dose-response study, using the commercial rice cultivars IRGA 417, IRGA 422 CL, and Puitá INTA CL. Based on the preliminary study, imazethapyr + imazapic (Only, 75+25 g L'-1, CS, BASF, São Paulo, Brazil) at $90+30 \mathrm{~g} \mathrm{ha}^{-1}$ was chosen to test the 1,008 red rice populations. This herbicide rate provided the maximum difference between IMI-susceptible 'IRGA 417' and the IMI-R rice 'IRGA 422 CL' and 'Puitá INTA CL'. In addition, nonionic surfactant was also added to the herbicide (Dash $\mathrm{HC}, 933 \mathrm{~g} \mathrm{~L}^{-1}$, CS, BASF, São Paulo, Brazil) at $466 \mathrm{~g} \mathrm{ha}^{-1}\left(0.5 \% \mathrm{v} \mathrm{v}^{-1}\right)$.

Herbicide applications were carried out when plants reached 3 to 4 leaves. The treatment was applied using a backpack sprayer, equipped with DG 80.01 spray nozzles delivering a spray volume of $100 \mathrm{~L} \mathrm{ha}^{-1}$, with $250 \mathrm{kPa}$ pressure at $1.0 \mathrm{~m} \mathrm{~s}^{-1}$. Applications were carried out in the early morning, at temperatures from 23 to $32^{\circ} \mathrm{C}$, relative air humidity from 69 to $92 \%$, and a wind velocity lower than $5 \mathrm{~km} \mathrm{~h}^{-1}$. The red rice control was assessed at 30 days after the applications (DAA) using a linear scale from 0 to $100 \%$. A population was considered susceptible when all replicates showed no surviving plants or control $\geq 80 \%$ (without producing viable seed); and it was considered resistant when one or more replicates had surviving plants or control $<80 \%$.

After susceptible or resistant scoring, the obtained binary data were converted to numeric data (susceptible $=0$; resistant $=1$ ), in order to quantify the percentage of IMI-R red rice populations. The data of control and percentage of resistance were subjected to the analysis of variance using a mixed model in the JMP program, version 12.2.0 (SAS Institute Inc., Cary, NC). Rice growing seasons, production regions, and their interaction were modeled as fixed effects, while other factors were modeled as random effects. The significance of fixed effects was evaluated with the F-approximate test $(\mathrm{p} \leq 0.05)$, and the least square means of treatments were compared by Tukey's test, at $5 \%$ probability.

Additionally, the identification of the ALS (acetolactate synthase) alleles Ala122Thr, Ser653Asn, and Gly654Glu, associated with the IMI-R cultivars IRGA 422 CL, Puitá INTA CL, and SATOR CL, respectively, was performed by single nucleotide polymorphism (SNP) molecular markers, as described in Roso et al. (2010). These analyses were carried out in samples from the growing seasons $2006 / 2007(\mathrm{n}=124)$, $2007 / 2008(n=255)$ and $2009 / 2010(n=381)$, in order to identify the evolution of the resistance, and relate it to the gene flow from the different CL rice cultivars. Genomic DNA was obtained from approximately $150 \mathrm{mg}$ leaf tissue from each red rice plant, and from 'IRGA 417' (susceptible), 'IRGA 422 CL', 'Puitá INTA CL', and 'SATOR CL' as controls. The DNA extraction and quantification and PCR assay were performed as described in Roso et al. (2010). The frequency of each ALS allele was calculated for each red rice population in the three growing seasons. The molecular data were analyzed by a chi-square test, at $5 \%$ probability.

Also, forty rice growers of the RS state were selected to a survey for their agronomic practices applied to red rice control, in the growing seasons from $2005 / 2006$ to $2012 / 2013$. These growers were previously selected because they had a history of problems with red rice control, and they recorded data on the main field activities over the last eight growing seasons. In each farm, a regional customer agronomist of IRGA's Extension, have personally surveyed the selected growers' practices "on farm" for: area and level of adoption of IMI herbicide usage; certified seed usage; control of red rice escapees; their own harvest machinery; and crop rotation systems. The numeric answers were converted to a per hectare proportion for each farm, and to a percentage in relation to the respective production region. Data were subjected to the analysis of variance and mean comparison, using the same method and criteria previously described for the data of the percentage of IMI-R red rice populations.

\section{Results and discussion}

The red rice control assessed at 30 DAA varied only as a function of rice growing seasons $(\mathrm{p}<0.0001)$ (Figure 1). The average control gradually decreased from 71.1 to $5.2 \%$ in the growing seasons from $2006 / 2007$ to $2011 / 2012$. Considering the red rice populations classified as IMI-R only, the control average values ranged from 44.1 to $5.2 \%$, respectively, from the 2006/2007 to 2011/2012 growing seasons. Most of red rice populations evaluated in the 2010/2011 and 2011/2012 growing seasons showed high levels of resistance to IMI-herbicides. 
For the percentage of IMI-R red rice populations, there was interaction between rice growing seasons and production regions $(\mathrm{p}<0.0001)$ at 30 DAA (Table 1). Despite the fact that IMI-R red rice was

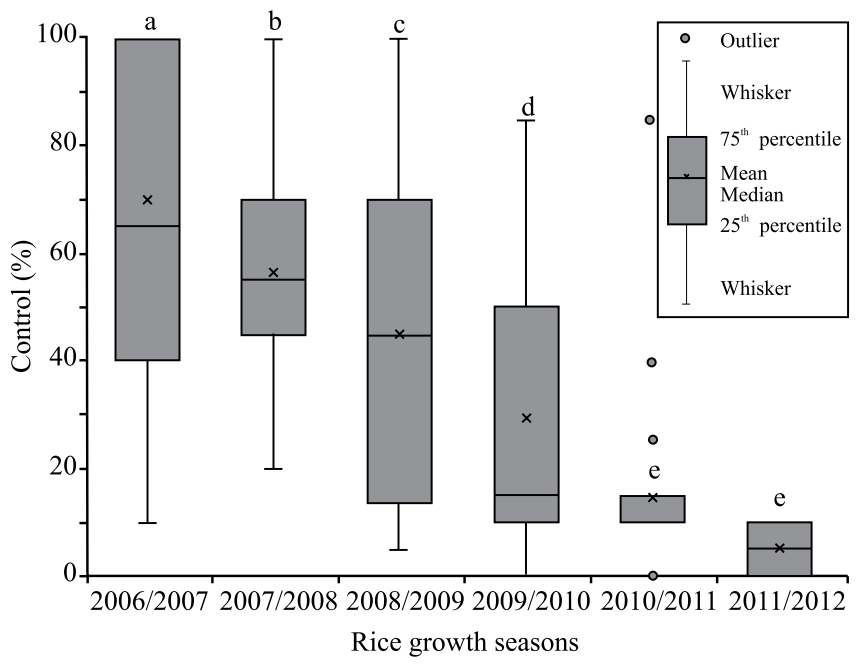

Figure 1. Number of imidazolinone-resistant red rice (Oryza sativa) populations at 30 days after application, in six rice growing seasons (average of six rice production regions), in the state of Rio Grande do Sul, Brazil. Means followed by equal letters do not differ from each other, by Tukey's test, at 5\% probability. Number of populations, in each growing season, was: 228 (2006/2007), 267 (2007/2008), 310 (2008/2009), 140 (2009/2010), 44 (2010/2011), and 19 (2011/2012). widespread throughout the RS since the 2006/2007 growing season, there were differences in space and time across the rice production regions. IMI-R red rice populations were $56,73,68,76,100$, and $100 \%$, respectively, in the growing seasons of 2006/2007, 2007/2008, 2008/2009, 2009/2010, 2010/2011, and 2011/2012. Additionally, the percentage of IMI-R red rice varied between production regions, and it was higher in the Depressão Central and Fronteira Sul, in comparison to the other production regions.

IMI-R red rice was detected after 2.7 growing seasons after the beginning of the use of CL rice cultivars, with average values by production region ranging from 1.6 to 3.5 growing seasons. These results indicate that the problem of IMI-R red rice occurred sooner in the selected rice fields of Brazil than in rice fields in Southern USA (Burgos et al., 2008; Dauer et al., 2018) and Italy (Busconi et al., 2012), where IMI-R red rice was identified after 5 years of CL rice commercial use. In USA rice fields, crop rotation is largely used, and the adoption of certified seeds is high (Sudianto et al., 2013; Ziska et al., 2015). These factors explain the large differences for the period of the first appearance of IMI-R red rice between Brazil and the USA.

ALS alleles frequency differed for rice growing seasons (Figure 2). The Gly654Glu mutation was

Table 1. Distribution of imidazolinone-resistant (IMI-R) red rice (Oryza sativa) populations (POP) in six rice growing seasons (2006/2007, 2007/2008, 2008/2009, 2009/2010, 2010/2011, and 2011/2012) and six production regions, in the state of Rio Grande do Sul, Brazil ${ }^{(1)}$.

\begin{tabular}{|c|c|c|c|c|c|c|c|c|c|c|c|c|}
\hline \multirow[t]{2}{*}{ Production regions } & \multicolumn{2}{|c|}{$2006 / 2007$} & \multicolumn{2}{|c|}{$2007 / 2008$} & \multicolumn{2}{|c|}{$2008 / 2009$} & \multicolumn{2}{|c|}{$2009 / 2010$} & \multicolumn{2}{|c|}{$2010 / 2011$} & \multicolumn{2}{|c|}{$2011 / 2012$} \\
\hline & $\begin{array}{l}\text { POP } \\
(\mathrm{n})^{(2)}\end{array}$ & $\begin{array}{l}\text { IMI-R } \\
(\%)^{(2)}\end{array}$ & $\begin{array}{l}\text { POP } \\
\text { (n) }\end{array}$ & $\begin{array}{c}\text { IMI-R } \\
(\%)\end{array}$ & $\begin{array}{l}\text { POP } \\
\text { (n) }\end{array}$ & $\begin{array}{c}\text { IMI-R } \\
(\%)\end{array}$ & $\begin{array}{l}\text { POP } \\
\text { (n) }\end{array}$ & $\begin{array}{c}\text { IMI-R } \\
(\%)\end{array}$ & $\begin{array}{l}\text { POP } \\
\text { (n) }\end{array}$ & $\begin{array}{c}\text { IMI-R } \\
(\%)\end{array}$ & $\begin{array}{l}\text { POP } \\
\text { (n) }\end{array}$ & $\begin{array}{c}\text { IMI-R } \\
(\%)\end{array}$ \\
\hline Depressão Central & 82 & $68 \mathrm{Db}$ & 116 & $91 \mathrm{Ba}$ & 89 & $69 \mathrm{Db}$ & 18 & $78 \mathrm{Cc}$ & 4 & $100 \mathrm{Aa}$ & 1 & $100 \mathrm{Aa}$ \\
\hline Planície Costeira Interna & 38 & 32Df & 40 & $65 \mathrm{Cb}$ & 27 & $63 \mathrm{Cc}$ & 24 & $96 \mathrm{Ba}$ & 2 & $100 \mathrm{Aa}$ & 5 & $100 \mathrm{Aa}$ \\
\hline Planície Costeira Externa & 23 & 57Dc & 27 & $63 \mathrm{Cb}$ & 68 & $82 \mathrm{Ba}$ & 44 & 59Dd & 5 & $100 \mathrm{Aa}$ & 4 & $100 \mathrm{Aa}$ \\
\hline Fronteira Sul & 35 & $77 \mathrm{Ba}$ & 42 & $57 \mathrm{Cc}$ & 57 & $79 \mathrm{Ba}$ & 23 & $78 \mathrm{Bc}$ & 13 & $100 \mathrm{Aa}$ & 7 & $100 \mathrm{Aa}$ \\
\hline Fronteira Oeste & 22 & 45Dd & 19 & $53 \mathrm{Cc}$ & 25 & $56 \mathrm{Cd}$ & 8 & $88 \mathrm{Bb}$ & 4 & $100 \mathrm{Aa}$ & 1 & $100 \mathrm{Aa}$ \\
\hline Zona Sul & 28 & $36 \mathrm{Ee}$ & 23 & 39Dd & 44 & 41De & 23 & $78 \mathrm{Cc}$ & 16 & $94 \mathrm{Bb}$ & 1 & $100 \mathrm{Aa}$ \\
\hline Total (state) & 228 & 56 & 267 & 73 & 310 & 68 & 140 & 76 & 44 & 98 & 19 & 100 \\
\hline F test & \multicolumn{12}{|c|}{2.76} \\
\hline Probability & \multicolumn{12}{|c|}{$<0.0001$} \\
\hline Coefficient of variation (\%) & \multicolumn{12}{|c|}{66.42} \\
\hline
\end{tabular}

${ }^{(1)}$ Means followed by equal letters, lowercase in the columns and uppercase in the rows, do not differ, by Tukey's test, at $5 \%$ probability. ${ }^{(2)} \mathrm{POP}$, (n), number of red rice populations; IMI-R (\%), percentage of imidazolinone-resistant red rice populations. 
the most frequent compared to the other evaluated mutations. Gly654Glu is the IMI-R mutation present in 'IRGA 422 CL', the first CL rice cultivar commercialized in Southern Brazil since the 2002/2003 growing season. Although these results were expected for the first growing season (2006/2007), a frequency increase of Ala122Thr mutations due to the adoption of 'Puitá INTA CL' was not observed. Since the 2007/2008 growing season, 'IRGA 422 CL' was gradually replaced by 'Puitá INTA CL' and hybrid cultivars, primarily 'SATOR CL', at lower frequencies. Both 'Puitá INTA CL' and 'SATOR CL' show have higher levels of IMIresistance.

In the present study, the allele Ala122Thr was also detected in samples of red rice showing the IMI-R trait, although this mutation occurred in a small proportion of samples (Figure 2). A paternity exclusion analysis indicated that the origin of red rice resistance is due to independent selection in only $1.1 \%$ of the resistant plants, and that gene flow from the IMI-R cultivars is responsible for the resistance in $98.9 \%$ plants (Goulart et al., 2014). This result explains the close relationship between the prevalent rice cultivars used and the ALS

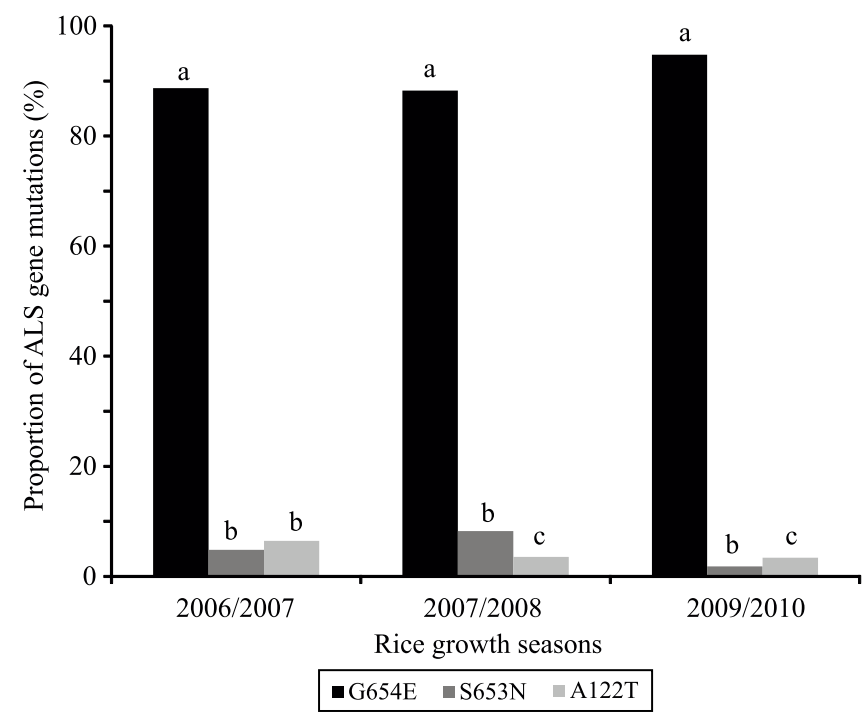

Figure 2. Proportion of acetolactate synthase (ALS) gene mutations in imidazolinone-resistant red rice (Oryza sativa) populations, in three rice growing seasons (average of six production regions), in Rio Grande do Sul state, Brazil. Means followed by equal letters do not differ from each other, by the chi-square test, at 5\% probability. Number of samples, in each growing season, was: 124 (2006/2007), 255 (2007/2008), and $381(2009 / 2010)$. allele found in the IMI-R red rice plants. Considering that the samples were collected when 'Puitá INTA CL' was just released, the resistant allele of this cultivar was found in a small proportion of samples in our study. In the following years, most areas were cultivated with 'Puitá INTA CL' and CL hybrids, which had high levels of IMI resistance and provided a high control of red rice. When these cultivars and higher doses of IMI herbicides - applied at pre- and post-emergence - began to be used, the farmers reported a better control of red rice than in previous years. However, a few seasons later, a large occurrence of escapees was observed again, which may be associated with the ALS alleles Ala122Thr and Ser653Asn carried by current CL rice cultivars. These results are related to the introgression among cultivated and red (Song et al., 2017) and wild rice (Wang et al., 2017), which is a challenge for the sustainability of technologies for herbicide-tolerance in rice crop.

IMI herbicide usage varied as a function of growing seasons $(p<0.001)$ (Figure 3$)$. The survey results indicate that $37 \%$ of flooded rice fields had been treated with IMI herbicides in the 2005/2006 growing

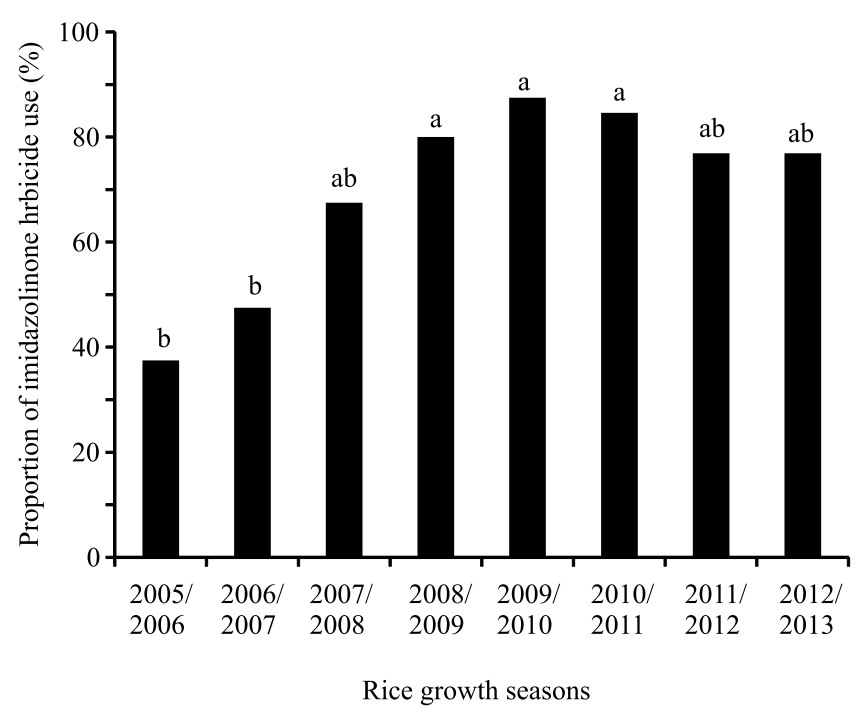

Figure 3. Proportion of imidazolinone herbicide use for weed control on flooded rice (Oryza sativa) fields, considering at least one application to the crop either in the pre- or postemergence, or in both phases, in eight rice growing seasons, in Rio Grande do Sul state, Brazil. Means followed by equal letters do not differ from each other, by Tukey's test, at $5 \%$ probability. Average of six rice production regions. 
season, three years after the release of 'IRGA 422 CL'. The use of this herbicide, from the 2005/2006 to 2012/2013 growing seasons, showed a similar adoption to that of CL rice cultivars, and reached the peak of adoption in the $2009 / 2010$ seasons ( $82 \%$ of the flooded rice fields).

When IMI herbicides did not completely control red rice plants in the CL rice fields, roguing was manually performed, and manual spraying of escapees was used only in $63 \%$ of the situations (Table 2). The South Zone was a unique rice production region where all selected growers adopted some type of roguing for controlling red rice escapees into the crop. The certified seed usage varied as a function of the rice production regions $(p<0.001)$. Only $36 \%$ of the selected growers have used certified seed in the implementation of the rice fields, and growers from four of the six regions have used less than $30 \%$ of certified seed. The production regions - Depressão Central, Planície Costeira Interna, Fronteira Sul, and Fronteira Oeste - showed the lowest

Table 2. Level of adoption of agronomic practices applied to red rice (Oryza sativa) control in flooded rice fields, in six rice production regions (average of eight growing seasons), in the state of Rio Grande do Sul, Brazil ${ }^{(1)}$.

\begin{tabular}{lccccc}
\hline Production regions & (n) & ---------- Management practices (\%) ------- \\
\cline { 2 - 6 } & & $\begin{array}{c}\text { Certified } \\
\text { seed }^{(2)}\end{array}$ & $\begin{array}{c}\text { Control of } \\
\text { escapees }^{(3)}\end{array}$ & $\begin{array}{c}\text { Own } \\
\text { machinery }^{(4)}\end{array}$ & $\begin{array}{c}\text { Crop } \\
\text { rotation }\end{array}$ \\
\hline Central valley & 8 & $0 \mathrm{~b}$ & $75 \mathrm{ab}$ & 88 & 0 \\
$\begin{array}{l}\text { Planície Costeira } \\
\text { Interna }\end{array}$ & 3 & $25 \mathrm{ab}$ & $75 \mathrm{ab}$ & 33 & 33 \\
Planície Costeira & 6 & $83 \mathrm{a}$ & $33 \mathrm{bc}$ & 100 & 17 \\
Externa & 12 & $13 \mathrm{~b}$ & $20 \mathrm{c}$ & 92 & 42 \\
Fronteira Sul & 8 & $25 \mathrm{ab}$ & $75 \mathrm{ab}$ & 88 & 63 \\
Fronteira Oeste & 3 & $67 \mathrm{ab}$ & $100 \mathrm{a}$ & 67 & 33 \\
Zona Sul & 40 & 36 & 63 & 78 & 31 \\
\hline Total (state) & - & 4.65 & 3.29 & 0.71 & 1.31 \\
\hline F test & - & 0.0024 & 0.0155 & 0.6218 & 0.2821 \\
Probability & - & 162.4 & 100.0 & 152.8 & 42.0 \\
CV $(\%)$ & & & & & \\
\hline
\end{tabular}

${ }^{(1)}$ Means followed by equal letters do not differ, by Tukey's test, at $5 \%$ probability. ${ }^{(2)}$ Certified seed are those whose production fields are inspected by regulatory agencies. ${ }^{(3)}$ Control of escapees were considered the roguing actions, such as manual removal of weedy rice, or herbicidesprayed escapees. ${ }^{(4)}$ Own harvest machinery was considered machinery used only in the rice fields of the grower. rates of certified seed usage, in comparison to the other regions.

For harvest machinery and crop rotation, the effect of rice growing seasons, production region, and their interaction was not significant. Twenty-two percent of the selected growers had harvested their rice fields using machinery from third parties, which may be highly contaminated with IMI-R red rice seed. Additionally, approximately $30 \%$ of those growers had adopted crop rotation systems, and the preferred crops used in rotation with rice were soybean (28\%) and corn $(2 \%)$.

The survey study indicated a very low adoption of good management practices to minimize the evolution and spread of IMI-R red rice in flooded rice fields (Figure 3; Table 2). Although all selected growers have faced recurrent problems with red rice and its control, only $42 \%$ of them reported confirmation or at least suspicion of the presence of IMI-R populations. Economic factors are considered the main explanation for the low adoption of certified seed, although the extra value of certified seed represents only approximately $2 \%$ of the total cost. In addition to the use of certified seed, planting CL rice cultivars for more than two consecutive years is not recommended. Another recommended practice of the managing program is the roguing of escapees, especially in crop rotation, which had also been minimally adopted (Table 2). Preventive strategies on decreasing seed production and dispersion are essential for red rice management (Rao et al., 2017). Therefore, the failure in adopting these practices, as above described, may be directly associated with the problems of the red rice control in the evaluated regions.

IMI-R red rice populations were widespread throughout the RS state since the 2006/2007 growing season, and occurred faster and were more frequent in the Depressão Central and Fronteira Sul production regions (Table 1), which had a lower adoption of certified seed and control of escapees, or crop rotation, in comparison to the other rice production regions of Rio Grande do Sul state (Table 2). Crop rotation was used by $31 \%$ of the farmers. This proportion is similar to the use of this practice in the recent growing seasons. Although soybean prices have been relatively high in the recent years, which favors the use of rotation with this crop, the limit of using $30 \%$ of the area for crop rotation had not been crossed. 


\section{Conclusions}

1. IMI-R red rice populations are widespread throughout the state of Rio Grande do Sul, Brazil, since the 2006/2007 growing season, and their initial frequency is higher in the Depressão Central and Fronteira Sul production regions.

2. Gly654Glu is the most frequent acetolactatesyntase (ALS) mutation in IMI-R red rice populations, which shows that gene flow occurs from the most used 'Clearfield' rice to red rice plants.

3. Crop rotation systems and certified seed are used by only $30 \%$ of 'Clearfield' rice growers, in the state of Rio Grande do Sul, with lower percentages in the production regions where IMI-R red rice appeared sooner.

\section{Acknowledgments}

To Conselho Nacional de Desenvolvimento Científico e Tecnológico (CNPq), for financial support; and to rice growers and customer agronomists of Instituto Rio Grandense do Arroz (IRGA), for providing the red rice samples and for surveying the selected growers.

\section{References}

BURGOS, N.R.; KORSWORTHY, J.K.; SCOTT, R.C.; SMITH, K.L. Red rice (Oryza sativa) status after 5 years of imidazolinoneresistant rice technology in Arkansas. Weed Technology, v.22, p.200-208, 2008. DOI: https://doi.org/10.1614/WT-07-075.1.

BUSCONI, M.; ROSSI, D.; LORENZONI, C.; BALDI, G.; FOGHER, C. Spread of herbicide-resistant weedy rice (red rice, Oryza sativa L.) after 5 years of Clearfield rice cultivation in Italy. Plant Biology, v.14, p.751-759, 2012. DOI: https://doi.org/10.1111/ j.1438-8677.2012.00570.x.

BZOUR, M.I.; ZUKI, F.M.; MISPAN, M.S. Introduction of imidazolinone herbicide and Clearfield ${ }^{\circledR}$ rice between weedy ricecontrol efficiency and environmental concerns. Environmental Reviews, v.26, p.181-198, 2018. DOI: https://doi.org/10.1139/er2017-0096.

CONAB. Companhia Nacional de Abastecimento. Grãos - Série Histórica: arroz: área, produtividade e produção. 2018. Available at: <https://portaldeinformacoes.conab.gov.br/index.php/safras/ safra-serie-historica>. Accessed on: Oct. 12018.

CRUZ, R.P. Exigências climáticas para a cultura do arroz irrigado. Cachoeirinha: IRGA, 2010. 40p. (IRGA. Boletim técnico, 11).

DAUER, J.; HULTING, A.; CARLSON, D.; MANKIN, L.; HARDEN, J.; MALLORY-SMITH, C. Gene flow from single and stacked herbicide-resistant rice (Oryza sativa): modeling occurrence of multiple herbicide-resistant weedy rice. Pest Management Science, v.74, p.348-355, 2018. DOI: https://doi.org/10.1002/ps.4711.

DELOUCHE, J.C.; BURGOS, N.R.; GEALY, D.R.; SAN MARTÍN, G.Z. DE; LABRADA, R.; LARINDE, M.; ROSSEL, C. Weedy rices: origin, biology, ecology and control. Rome: FAO, 2007. 188p. (FAO. Plant Production and Paper, 188).

DURAND-MORAT, A.; NALLEY, L.L.; THOMA, G. 2018. The implications of red rice on food security. Global Food Security, v.18, p.62-75, 2018. DOI: https://doi.org/10.1016/j.gfs.2018.08.004.

ELLSTRAND, N.C. Does introgression of crop alleles into wild and weedy living populations create cryptic in situ germplasm banks? Molecular Ecology, v.27, p.38-40, 2018. DOI: https://doi.org/10.1111/mec.14390.

GAO, P.; ZHANG, Z.; SUN, G.; YU, H.; QIANG, S. The withinfield and between-field dispersal of weedy rice by combine harvesters. Agronomy for Sustainable Development, v.38, art.55, 2018. DOI: https://doi.org/10.1007/s13593-018-0518-2.

GEALY, D.R.; MITTEN, D.H.; RUTGER, J.N. Gene flow between red rice (Oryza sativa) and herbicide-resistant rice $(O$. sativa): implications for weed management. Weed Technology, v.17, p.627-645, 2003. DOI: https://doi.org/10.1614/WT02-100.

GOULART, I.C.G. dos R.; PACHECO, M.T.; NUNES, A.L.; MENEZES, V.G.; MEROTTO JR., A. Identification of origin and analysis of population structure of field-selected imidazolinoneherbicide resistant red rice (Oryza sativa). Euphytica, v.187, p.437-447, 2012. DOI: https://doi.org/10.1007/s10681-012-0738-5.

GOULART, I.C.G.R.; BORBA, T.C.O.; MENEZES, V.G.; MEROTTO JR., A. Distribution of weedy red rice (Oryza sativa) resistant to imidazolinone herbicides and its relationship to rice cultivars and wild Oryza species. Weed Science, v.62, p.280-293, 2014. DOI: https://doi.org/10.1614/WS-D-13-00126.1.

KANAPECKAS K.L.; TSENG, T.-M.; VIGUEIRA, C.C.; ORTIZ, A.; BRIDGES, W.C.; BURGOS, N.R.; FISCHER, A.J.; LAWTON-RAUH, A. Contrasting patterns of variation in weedy traits and unique crop features in divergent populations of US weedy rice (Oryza sativa sp.) in Arkansas and California. Pest Management Science, v.74, p.1404-1415, 2018. DOI: https://doi. org/10.1002/ps.4820.

MENEZES, V.G.; MARIOT, C.H.P.; KALSING, A.; FREITAS, T.F.S. de; GROHS, D.S.; MATZENBACHER, F. de O. Associação de glyphosate e imidazolinonas no controle de arroz-vermelho em arroz Clearfield®. Ciência Rural, v.43, p.2154-2159, 2013. DOI: https://doi.org/10.1590/S0103-84782013001200006.

MENEZES, V.G.; MARIOT, C.H.P.; KALSING, A.; GOULART, I.C.G.R. Red rice (Oryza sativa) resistant to the herbicides imidazolinones. Planta Daninha, v.27, p.1047-1052, 2009. Número especial. DOI: https://doi.org/10.1590/S010083582009000500018.

MEROTTO JR, A.; GOULART, I.C.G.R.; NUNES, A.L.; KALSING, A.; MARKUS, C.; MENEZES, V.G. ; WANDER, A.E. Evolutionary and social consequences of introgression of nontransgenic herbicide resistance from rice to weedy rice in 
Brazil. Evolutionary Applications, v.9, p.837-846, 2016. DOI: https://doi.org/10.1111/eva.12387.

NADIR, S.; XIONG, H.-B.; ZHU, Q.; ZHANG, X.-L.; XU, H.-Y.; LI, J.; DONGCHEN, W.; HENRY, D.; GUO, X.-Q.; KHAN, S.; SUH, H.-S.; LEE, D.S.; CHEN, L.-J. Weedy rice in sustainable rice production. A rewiew. Agronomy for Sustainable Development, v.37, art.46, 2017. DOI: https://doi.org/10.1007/s13593-017-0456-4.

RAO, A.N.; BRAINARD, D.C.; KUMAR, V.; LADHA, J.K.; JOHNSON, D.E. Preventive weed management in direct-seeded rice: targeting the weed seedbank. In: SPARKS, D.L. (Ed.). Advances in Agronomy. Cambridge: Elsevier, 2017. v.144, p.45142. DOI: https://doi.org/10.1016/bs.agron.2017.02.002.

ROSO, A.C.; MEROTTO JR, A.; DELATORRE, C.A.; MENEZES, V.G. Regional scale distribution of imidazolinone herbicide-resistant alleles in red rice (Oryza sativa L.) determined through SNP markers. Field Crops Research, v.119, p.175-182, 2010. DOI: https://doi.org/10.1016/j.fcr.2010.07.006.

SINGH, V.; SINGH, S.; BLACK, H.; BOYETT, V.; BASU, S.; GEALY, D.; GBUR, E.; PEREIRA, A.; SCOTT, R.C.; CAICEDO, A.; BURGOS, N.R. Introgression of Clearfield ${ }^{\mathrm{TM}}$ rice crop traits into weedy red rice outcrosses. Field Crops Research, v.207, p.13-23, 2017. DOI: https://doi.org/10.1016/j.fcr.2017.03.004.

SONG, D.-Y.; WANG, Z.; SONG, Z.-J.; ZHOU, C.-C.; XU, P.-H.; YANG, J.; YANG, J.; LU, B.-R. Increased novel single nucleotide polymorphisms in weedy rice populations associated with the change of farming styles: implications in adaptive mutation and evolution. Journal of Systematics and Evolution, v.55, p.149157, 2017. DOI: https://doi.org/10.1111/jse.12230.

SUDIANTO, E.; BENG-KAH, S.; TING-XIANG, N.; SALDAIN, N.E.; SCOTT, R.C.; BURGOS, N.R. Clearfield ${ }^{\circledR}$ rice: its development, success, and key challenges on a global perspective. Crop Protection, v.49, p.40-51, 2013. DOI: https://doi.org/10.1016/j.cropro.2013.02.013.

WANG, H.; VIEIRA, F.G.; CRAWFORD, J.E.; CHU, C.; NIELSEN, R. Asian wild rice is a hybrid swarm with extensive gene flow and feralization from domesticated rice. Genome Research, v.27, p.1029-1038, 2017. DOI: https://doi.org/10.1101/ gr.204800.116.

ZHANG, W.; LINSCOMBE, S.D.; WEBSTER, S.; TAN, S.; OARD, J. Risk assessment of the transfer of imazethapyr herbicide tolerance from Clearfield rice to red rice (Oryza sativa). Euphytica, v.152, p.75-86, 2006. DOI: https://doi.org/10.1007/ s10681-006-9180-x.

ZISKA, L.H.; GEALY, D.R.; BURGOS, N.; CAICEDO, A.L.; GRESSEL, J.; LAWTON-RAUH, A.L.; AVILA, L.A.; THEISEN, G.; NORSWORTHY, J.; FERRERO, A.; VIDOTTO, F.; JOHNSON, D.E.; FERREIRA, F.G.; MARCHESAN, E.; MENEZES, V.G.; COHN, M.A.; LINSCOMBE, S.; CARMONA, L.; TANG, R.; MEROTTO JR., A. Weedy (red) rice: an emerging constraint to global rice production. In: SPARKS, D.L. (Ed.). Advances in Agronomy. Cambridge: Elsevier, 2015. v.129, p.181228. DOI: https://doi.org/10.1016/bs.agron.2014.09.003. 